\title{
The Moderating Effect of Subjective Norm on Cloud Computing Users' Perceived Risk and Usage Intention
}

\author{
Hsinkuang Chi ${ }^{1}$, Hueryren Yeh $^{2}$ \& Wei-chien Hung ${ }^{1}$ \\ ${ }^{1}$ Faculty of Department of Business Administration, Nanhua University, Chiayi, Taiwan \\ ${ }^{2}$ Faculty of Department of Marketing Management, Shih Chien University, Kaoshiung, Taiwan \\ Correspondence: Hsinkuang Chi, Faculty of Department of Business Administration, Nanhua University, 55 Sec. \\ 1, Nau Hua Rd., Dalin, Chiayi 622, Taiwan, R.O.C. Tel: 886-5-272-1001 Ext. 50207. E-mail: \\ hkchi@mail.nhu.edu.tw
}

Received: August 8, 2012 Accepted: September 7, 2012 Online Published: November 2, 2012

doi:10.5539/ijms.v4n6p95 URL: http://dx.doi.org/10.5539/ijms.v4n6p95

\begin{abstract}
The high popularity and high demand of internet applications lead to faster development of cloud computing services that make network access become more convenient. However, using a new technology can cause users' perceived risk because they worry about internet security and invasion of privacy. The study aims to explore the influence of end users' perceived risk on usage intention of cloud computing services and the interactive effect of perceived risk and subjective norm on usage intention. The study dispatched 350 questionnaires to internet users. The amount of valid questionnaires is 238 and the effective response rate is $68 \%$. The results showed that both perceived risk and subjective norm are significantly affected to usage intention, and subjective norm has a moderating effect on the relationship between perceived risk and usage intention.
\end{abstract}

Keywords: perceived risk, subjective norm, usage intention, cloud computing services, moderating effect

\section{Introduction}

According to Foreseeing Innovative New Digiservice (FIND, 2010b), the total number of fixed broadband internet subscribers reached 5.05 million, and social networks such as Facebook providing by cloud computing services were up to 8.0 million users in Taiwan. Ellison, Steinfield, \& Lampe (2007) suggested that peers and network societies often influence users to join social networks to develop interpersonal relationship. However, in order to understand the current usage condition and future need for the use of data storage in cloud computing services, Institute of Information Industry (III) performed an online survey and found that over sixty percent of respondents replied that they were willing to use the services but they concerned more about invasion of privacy and personal information leakage (FIND, 2010a). It is obvious that information security of cloud computing services is the most important issue concerned by the public. The study is to explore the influence of end users' perceived risk on usage intention of cloud computing services and to examine whether subjective norm is a moderating variable between the relationship of perceived risk and usage intention.

\section{Literature Review}

\subsection{Cloud Computing Services}

Cloud computing is a model for enabling ubiquitous, convenient, on-demand network access to a shared pool of configurable computing resources (e.g., networks, servers, storage, applications, and services) (Wikimedia, 2011). Computer World indicated that cloud computing can be divided into two categories: cloud computing services and cloud computing technologies (Huang, 2009). Cloud computing services focus on remote access to services and computing resources provided over the Internet "cloud" which include software as a service (SaaS) applications such as Customer Relationship Management (CRM) and payroll services, as well as vendors that offer access to storage and processing power over the Web (Brodkin, 2008). Cloud computing technologies emphasizes on the use of technologies such as virtualization and automation that enable the creation and delivery of service-based computing capabilities. This category is "an extension of traditional data center approaches and can be applied to entirely internal enterprise systems with no use of external off-premises capabilities provided by a third party" (Brodkin, 2008), so it is also called "private cloud" (Huang, 2009)." Although the study has mentioned some cloud computing technologies, the majority of the research concentrated on applications of 
cloud computing services.

The first mover in cloud computing was Salesforce.com in 1999, which pioneered the concept of delivering enterprise applications via a simple website, and the next was Amazon which launched Amazon Web Services in 2002 (Mohamed, 2009). Then, Google, Microsoft, Yahoo search engine, Facebook and internet map providers all followed suit. This concept of cloud computing has been existed for a long time and has continuously expanded into an indispensable tool in peoples' life. It is believed that data storage and data access can go through the interface of cloud computing services and all information can be processed by cloud computing. The benefits of cloud computing services not only provide users better services but also help businesses to reduce cost and risk effectively. It is because cloud computing does not need install software into users' computer, it greatly reduces the risk of providers' programs being cracked. Cloud computing can also massively collect data and deliver data without spending large amounts cost and time in data transmission. By adopting cloud computing, managers or users in the same company around the world can use this same platform to cooperate each other more closely and timely.

\subsection{Perceived Risk}

The applications of cloud computing services in marketing, information search and social networking have become a new trend following by the fast development of internet technology globally. Unfortunately, the more the time users spend on the internet, the more chances for hackers break into system and increase the risk to disclose users' private information (Drennan, Mort, \& Previte, 2006). No matter which it is joining in marketing or social network activities online, users usually need to provide their personal and financial information to the party which they do not know. The requirement results in consumers' hesitation and causes perceived risk (Huang, Schrank, \& Dubinsky, 2004). Especially, when users log into social networking sites, they could encounter social media threats. These attacks usually contain malicious links and lead users to Phishing websites or download malware (Boquiron, 2011). That is why over $79 \%$ of internet users will quit a webpage browsing immediately once they are required to fill in personal information (Paul, 2001). Baird and Thomas (1985) considered that perceived risk is an individual's estimation and controllable level on an uncertain condition which will affect a consumer's decision to use a product (Dowling, 1986). Perceived risk can induce a negative effect on usage intention (Guseman, 1981) and arouse unfavorable effects when a buyer chooses a product in his or her buying situation (Bettman, 1973). From this viewpoint, it can refer that perceived risk is prevalent in cloud computing services because the system will record users' behavior, habit, and preference... at the same time when they use the services. Thus, uncertain risks and possible unfavorable effects make cloud computing users create "a subjective-determined expectation of loss" (Mitchell, 1999).

Many researches maintained that perceived risk in non-store (online) shopping is higher than in in-store shopping (Mitchell, 1992; Tan, 1999; Bhatnagar, Misra, \& Rao, 2000; Lee \& Tan, 2003; Forsythe \& Shi, 2003; Pires, Stanton, \& Eckford, 2004; Drennan, et al., 2006; Doolin, Dillon, S., \& Corner, 2006, Mansour \& Ali, 2009). Cloud computing service is a non-store service that users cannot examine the product beforehand (Biswas \& Biswas, 2004) so it contains internet security and privacy risk (Drennan, et al., 2006; Doolin, Dillon, Thompson, \& Corner, 2005; Mooney, 2000). As a result, the decision to use cloud computing services implies uncertain results and causes perceived risk (Ueltschy, Krampf, \& Yannopoulos, 2004, Drennan, et al., 2006; Doolin, et al., 2005, Pires, et al., 2004). On the research of e-commerce and internet virtual trading, Liebermann and Stashevsky's (2002) and Lu, Hsu and Hsu (2005) found that better personal information security will result in the increase in perceived risk and the decrease in usage intention. Wang (2009) asserted that perceived risk significantly affects to usage intention of smart phone online services and is a determinant whether users will adopt online buy-it-now auction on the C2C Market or not (Xu, Lin, \& Shao, 2010). Chi, Yeh, and Yang (2009) found that perceived risk will further influence users' usage intention in smart phone because they worry about practical function, service quality, and technical operation of a new technology. Drennan, et al. (2006) also found that end users' perceived risk will negatively affect to online subscription and purchasing behavior. Besides, hackers may lure users with malicious links to Phishing websites or download malware or send spam mails, which this can happen just by clicking "Like" at Facebook (Boquiron, 2011). Thus, although the users' acceptance rate of cloud computing services in Taiwan is high, they still concern about information security and invasion of privacy (FIND, 2010b). After all, to save personal information at an unseen internet network does cause public suspicion, so it needs to reduce internet security uncertainty to increase usage intention.

\subsection{Subjective Norm}

Theory of Reasoned Action (TRA) suggests that if someone wants to predict whether a person will perform a behavior, he or she has to understand the person's attitude and subjective norm to verify a certain behavioral 
intention (Fishbein \& Ajzen, 1975, 1980; Ajzen, 1991; Mathieson, 1991; Thompson, Higgins, \& Howell, 1991; Taylor \& Todd, 1995; Fishbein, 1980). TRA signals that attitude and subjective norm can explain people's behavioral intention and further predict their actual action. Subjective norm includes normative belief and motivation to comply. Normative belief refers to perceive the expectations of specific referent individuals or groups, and motivation to comply is the willingness to comply specific referent individuals' or groups' opinions. Several researches on internet shopping, social networking, internet knowledge sharing and new computer software usage pinpointed that subjective norm will significantly and positively affect to usage intention (Chao, Huang, \& Lin, 2009; Constant, Keisler, \& Sproull, 1994; Igbaria, Parasuraman, \& Baroudi, 1996; Venkatesh \& Morris, 2000). Subjective norm is a perceptive behavior which means pressures from society, culture, family and reference groups can influence individuals to comply a behavior (Meyer \& Allen, 1997). In addition, others' attitude will influence usage intention (Kotler, 2003), and reference groups from social networks are able to produce usage intention. For instance, people often join in Facebook's connection and interaction with others under friends' appeals or relatives' inducements. Cloud computing users will also incur a compliant behavior under friends' and relatives' influences or others' attitude. Accordingly, subjective norm has a positive influence on usage intention and users will comply to use cloud computing services because of subjective norm.

\subsection{Usage Intention}

Engel, Blackwell and Miniard (1995) suggested that usage intention is a psychological decision making process. When a user has a need, he or she will motivate to satisfy the need by searching relative information according to his and her own experience and external environment, then evaluating and considering all information, and deciding to use a product after comparison and judgment of other alternatives. Spears and Singh (2004) considered usage intention is a person's conscious plan to make an effort to buy a product. Technology Acceptance Model (TAM) indicates that usage intention is an instrument in measuring the strength of a user's willingness to use an innovative technology (Fishbein \& Ajzen 1975; Ajzen \& Fishbein, 1980; Ajzen, 1985). In internet applications, Lin (2006) researched on the willingness to use the wireless network on campus and concluded that perceived usefulness and perceived ease of use will affect usage intention. Chen (2003) further commented if service suppliers provide technological supports and interactions with users, their usage intention will increase. Yu (2009) indicated that attitude, subjective norm, and perceived behavioral control will affect the government employees' intention to use the Thin Client cloud computing service, and perceived behavioral control is the most important factor to influence usage intention. It implies the willingness of the government employees to use a new technology depends on the controllability of resources and opportunities. If users can obtain resource assistances, their willingness to use cloud computing services will be higher. Hsiao (2001) also pointed out the acceptance of cloud computing services in Taiwan is high but perceived risk of using cloud computing services still exists. Therefore, the study aims to explore the interactive effect of perceived risk and subjective norm on usage intention and the influence of end users' perceived risk of usage intention of cloud computing services.

\section{Research Methodology}

\subsection{Research Framework}

The study uses perceived risk as the independent variable, usage intention as the dependent variable and subjective norm as the moderating variable to explore whether perceived risk will be significantly affected to usage intention and the interactive effect of perceived risk and subjective norm will be significantly affected to usage intention.

\subsection{Research Hypotheses}

H1: Perceived risk will have a significant and negative effect on usage intention.

$\mathrm{H} 2$ : Subjective norm will have a significant and positive effect on usage intention.

H3: Subjective norm will moderate the relationship between perceived risk and usage intention.

\subsection{Research Sample}

The study uses the questionnaire as research instrument with a 7-point Likert scale (1=strongly disagree; $7=$ strongly agree) and adopts convenient sampling to collect data from internet users. 350 questionnaires were dispatched at companies, internet cafes, and computer classrooms and 273 copies were returned. The study excluded 18 invalid questionnaires and discarded 17 respondents who heard but did not clear what cloud computing services are. In the end, 238 copies were further used for data analysis. The effective response rate is $68 \%$. 


\section{Research Result}

\subsection{Sample Characteristics}

238 characteristics of the samples are described as follows: $88(36.9 \%)$ from companies, 48 (20.1\%) from internet cafes, and $102(42.8 \%)$ from computer classrooms. $142(60 \%)$ live in the central Taiwan, and $66(27.7 \%)$ live in the south of Taiwan. $77(32.4 \%)$ are male, and $161(67.6 \%)$ are female. $105(44.1 \%)$ are between 21 and 30 years old and $19(8 \%)$ are over 51 years old. $49(20.6 \%)$ are married and $189(79.4 \%)$ are single. $164(68.9 \%)$ are high school or university graduated. 193 (81.1\%) have experience in internet shopping. $223(93.7 \%)$ expresses that they have ever used social networks and 221 (92.9\%) know cloud computing services. 17 (7.1\%) ever heard but had no idea about cloud computing services .

\subsection{Reliability Analysis}

The study uses Cronbach's $\alpha$ to evaluate the internal consistency. The Cronbach's $\alpha$ is $0.771,0.766$ and 0.870 respectively to perceived risk, subjective norm, and usage intention. The results demonstrated that reliability is high because Cronbach's $\alpha$ is greater than 0.7 (Cuieford, 1965).

\subsection{Pearson Correlation Analysis}

The results of Pearson correlation analysis showed that perceived risk is negatively related to usage intention $(\mathrm{r}=$ $-0.259, p<0.01)$, and subjective norm is positively related to usage intention $(\mathrm{r}=0.232, p<0.01)$. Moreover, perceived risk and subjective norm are positively related $(\mathrm{r}=0.217, p<0.01)$.

\subsection{Moderating Effect Analysis}

The study controlled usage experience and degree of understanding to avoid interference from exogenous variables. As shown in Table 1, perceived risk is significantly affected to usage intention $(\beta=-0.201, p<0.001)$ in Model 2, and Subjective norm is significantly affected to usage intention $(\beta=0.266, p<0.001)$ in Model 3. Thus, $\mathrm{H} 1$ and $\mathrm{H} 2$ are supported. In addition, the result of Model 4 exhibited that the influence of usage intention on subjective norm is greater than that of perceived risk $(\beta=0.324>\beta=-0.273)$. Also, the interactive effect of perceived risk and subjective norm is significantly affected to usage intention $\left(\beta=0.144, R^{2}=0.284, p<0.05\right.$; Max VIF=1.206), and Adj. $R^{2}$ increases from 0.155 to 0.269 in Model 5. Accordingly, the results revealed that subjective norm holds an interactive effect with perceived risk on usage intention. H3 is sustained.

Table 1. Regression analysis of subjective norm, perceived risk and usage intention

\begin{tabular}{llllll}
\hline & Model 1 & Model 2 & Model 3 & Model 4 & Model 5 \\
\hline & $\begin{array}{l}\text { Usage } \\
\text { intention }\end{array}$ & $\begin{array}{l}\text { Usage } \\
\text { intention }\end{array}$ & $\begin{array}{l}\text { Usage } \\
\text { intention }\end{array}$ & $\begin{array}{l}\text { Usage } \\
\text { intention }\end{array}$ & $\begin{array}{l}\text { Usage } \\
\text { intention }\end{array}$ \\
\hline $\begin{array}{l}\text { Control variables } \\
\text { Usage experience and }\end{array}$ & $0.208^{\mathrm{c}}$ & $0.211^{\mathrm{c}}$ & $0.239^{\mathrm{c}}$ & $0.249^{\mathrm{c}}$ & $0.225^{\mathrm{c}}$ \\
$\begin{array}{l}\text { Degree of understanding } \\
\text { Independent variables }\end{array}$ & $0.238^{\mathrm{c}}$ & $0.180^{\mathrm{b}}$ & $0.227^{\mathrm{c}}$ & $0.159^{\mathrm{b}}$ & $0.144^{\mathrm{a}}$ \\
$\begin{array}{l}\text { Perceived risk } \\
\text { Moderating variables }\end{array}$ & & $-0.201^{\mathrm{c}}$ & & $-0.273^{\mathrm{c}}$ & $-0.277^{\mathrm{c}}$ \\
$\begin{array}{l}\text { Subjective norm } \\
\text { Perceived risk* }\end{array}$ & & & & \\
norm Subjective & & & $0.266^{\mathrm{c}}$ & $0.324^{\mathrm{c}}$ & $0.330^{\mathrm{c}}$ \\
$N$ & & & & & $0.144^{\mathrm{a}}$ \\
Max VIF & 238 & 238 & 238 & 238 & 238 \\
$F$-value & 1.125 & 1.126 & 1.139 & 1.141 & 1.206 \\
$R^{2}$ & $17.258^{\mathrm{c}}$ & $15.514^{\mathrm{c}}$ & $19.219^{\mathrm{c}}$ & $20.959^{\mathrm{c}}$ & $18.442^{\mathrm{c}}$ \\
Adj. $R^{2}$ & 0.128 & 0.166 & 0.198 & 0.265 & 0.284 \\
\hline
\end{tabular}

Note: ${ }^{\mathrm{a}}=p<0.05,{ }^{\mathrm{b}}=p<0.01,{ }^{\mathrm{c}}=p<0.001$

Meanwhile, in order to further understand the moderating effect of subjective norm between perceived risk and usage intention, the study adopted Aiken and West's (1991) suggestion to divide subjective norm into high level subject norm group and low level subjective norm group as well as plotted the diagram of interactive moderation effect. The result in Figure 1 exhibited a decreasing relationship on the interactive effect which showed that when perceived risk increases, the usage intention on cloud computing services will reduce. In addition, the 
influence of usage intention of high level subjective norm group is far less than low level subjective norm group does, which implies that high subjective norm group will not decrease usage intention, along with the increase of perceived risk.

\section{Conclusion and Suggestion}

The study found that perceived risk is significantly and negatively affected to usage intention. It means the higher users' perceived risk of cloud computing services is, the less usage intention is. That is, perceived risk is a major obstacle to cloud computing services. It suggests that users not only concern hackers may steal their personal information but also worry about management negligence of service providers. This kind of psychological distrust feeling is very hard to disappear. Therefore, the most important thing for cloud computing service providers is to solve users' worries and increase their confidence because the reduction of perceived risk can promote usage intention.

The study also discovered the influence of subjective norm is higher than perceived risk on usage intention. It tells that the influence of individual perceived behavior on usage intention is subject to the effects of society, culture, family, and reference groups' pressures. Hence, it implies that users will use cloud computing services or join social networks to develop human relationships even if there is an internet security risk. Subjective norm has a moderating effect which signifies that under the interactive effect of perceived risk and subjective norm, usage intention will gradually diminish. However, high level subject norm group will not reduce usage intention, even following the increase of perceived risk. It is to say that peers' or social communities' pressures can increase usage intention.

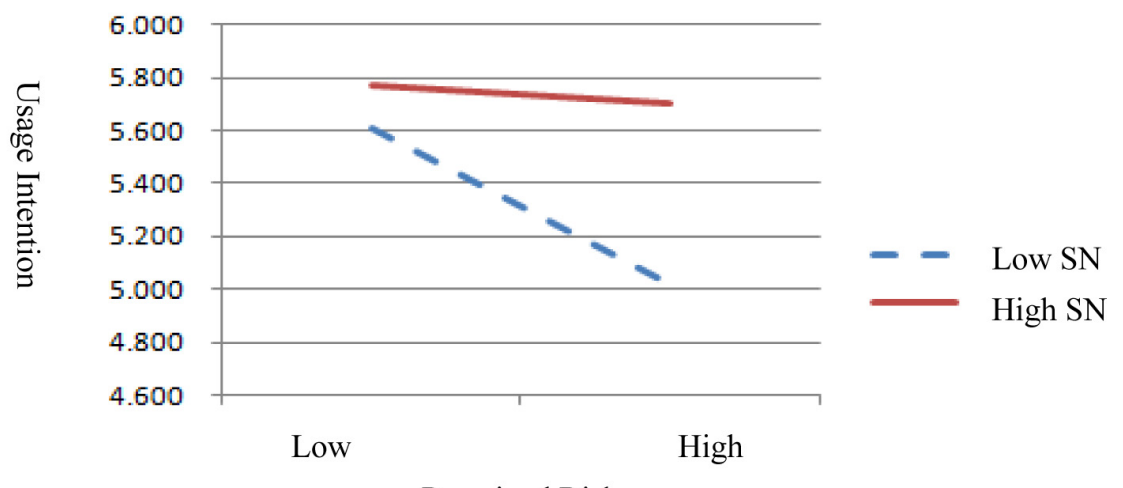

Perceived Risk

Figure 1. Moderating effect of subjective norm on perceived risk and usage intention

Note: $\mathrm{SN}=$ Subjective norm

Finally, the study recommends that cloud computing service providers need to build the most solid network security system to reduce users' perceived risk in order to raise usage intention. In the meantime, cloud computing service providers have to promote cloud computing services intensively to make the services become a trend for the public because the influence of subjective norm is greater than perceived risk. That is, peers' or social communities' opinions will pressure users to comply to use cloud computing services. Besides, cloud computing service providers have to let users understand the benefits and functions of cloud computing services that all information they need is in the services and they can open the gate to connect the world just by a finger.

\section{References}

Ajzen, I. (1985). From intentions to action: a theory of planned behavior. In J. Kuhland \& J. Beckman (Eds.), Action control: From cognitions to behavior (pp.11-39). Heidelberg: Springer-Verlag.

Ajzen, I. (1991). The theory of planned behavior, organizational behavior \& human. Decision Processes, 50(2), 179-211. http://dx.doi.org/10.1016/0749-5978(91)90020-T

Ajzen, I., \& Fishbein, M. (1980).Understanding attitude and predicting social behavior. NJ: Prentice-Hall, Inc.

Baird, I. S., \& Thomas, H. (1985). Toward a contingency model of strategic risk taking. The Academy of Management Review, 10(2), 230-243.

Bettman, J. R. (1973). Perceived risk and its components: A model and empirical test. Journal of Marketing 
Research, 184-190. http://dx.doi.org/10.2307/3149824

Bhatnagar, A., Misra, S., \& Rao, H. R. (2000). On risk, convenience and internet shopping behavior. Communications of the ACM, 43(11), 98-105. http://dx.doi.org/10.1145/353360.353371

Biswas, D., \& Biswas. A. (2004). The diagnostic role of signals in the context of perceived risks in online shopping: Do signals matter more on the Web. Journal of Interactive Marketing, 18, 30-45. http://dx.doi.org/10.1002/dir.20010

Boquiron, V. R. (2011). Spam, scams and other social media threats. Retrieved $15^{\text {th }}$ March, 2011 from http://about-threats.trendmicro.com/RelatedThreats.aspx?language $=$ us\&name $=\mathrm{Spam} \% 2 \mathrm{C}+\mathrm{Scams}+$ and $+\mathrm{Oth}$ er+Social+Media+Threats http://en.wikipedia.org/wiki/Cloud_computing

Brodkin, J. (2008). Cloud computing hype spurs confusion. Retrieved March 09, 2011 from http://www.computerworld.com/s/article/9115904/Cloud_computing_hype_spurs_confusion_Gartner_says

Chao, R. M., Huang, S. Y., \& Lin, C. C. (2009). A study on the user of the dispersion knowledge management under the Bliki media. Journal of Communications Management, 1(10), 1-36.

Chen, M. K. (2003). A study on campus wireless local area network (WLAN): Technology Acceptance Model(TAM). Unpublished master's thesis, National Kaohsiung Normal University, Taiwan.

Chi, H. K., Yeh, H. R., \& Yang, Y. T. (2009). The impact of brand awareness on consumer purchase intention: The mediating effect of perceived quality and brand loyalty. Journal of International Management Studies, 4(1), 135-144.

Constant, D., Keisler, S., \& Sproull, L. (1994). What's mine is ours, or is it: A study of attitudes about information sharing. Information Systems Research, 5, 400-421. http://dx.doi.org/10.1287/isre.5.4.400

Cuieford, J. P. (1965). Fundamental statistics in psychology and education (4th ed). New York: McGraw Hill.

Doolin, B., Dillon, S., \& Corner, J. L. (2006). Determinants of online purchasing behaviour. Retrieved March 09, 2011 from http://www.irma-international.org/viewtitle/4567/

Doolin, B., Dillon, S., Thompson, F., \& Corner, J. L. (2005). Perceived risk, the internet shopping experience and online purchasing behavior: A New Zealand perspective. Journal of Global Information Management, 13(2), 66-89. http://dx.doi.org/10.4018/jgim.2005040104

Dowling, G. (1986). Perceived risk: The concept and its measurement. Psychology and Marketing, 3(3), 193-210. http://dx.doi.org/10.1002/mar.422003030

Drennan, J., Mort, G. S., \& Previte, J. (2006). Privacy, risk perception, and expert online behavior: Anexploratory study of household end users. Journal of Organizational and End User Computing, 18(1), 1-22. http://dx.doi.org/10.4018/joeuc.2006010101

Ellison, N. B., Steinfield, C., \& Lampe, C. (2007). The benefits of Facebook friends: Social capital and college students' use of online social network sites. Journal of Computer-Mediated Communication, 12, 1143-1168. http://dx.doi.org/10.1111/j.1083-6101.2007.00367.x

Engel, J. F., Blackwell, R. D., \& Miniard, P. W. (1995). Consumer behavior (6th ed). New York: Dryden Press.

Fishbein, M., \& Ajzen, I. (1975). Belief, attitude, intention and behavior: An introduction to theory and research. Journal of Leisure Research, 27(1), 61-84.

Fishbein, M., \& Ajzen, I. (1980). Understanding attitudes and predicting social behavior. Englewood Cliffs, NJ: Prentice Hall.

Foreseeing Innovative New Digiservice. (FIND, 2010a). 2010 Survey on enterprise demand for cloud computing service. Retrieved March 09, 2011 from http://books.find.org.tw/newbook_disp.asp?book_id=142

Foreseeing Innovative New Digiservice. (FIND, 2010b). 2010 Q4 Internet subscribers in Taiwan. Retrieved March 09, 2011 from http://www.find.org.tw/find/home.aspx?page=many\&id=169

Forsythe, S. M., \& Shi, B. (2003). Consumer patronage and risk perceptions in internet shopping. Journal of Business Research, 56, 867-875. http://dx.doi.org/10.1016/S0148-2963(01)00273-9

Guseman, D. (1981). Risk perception and risk reduction in consumer services. In Donnelly, J. H., \& W. George(Eds.), Marketing of Services (pp. 200-204). Chicago, IL: American Marketing Association.

Hsiao, H. C. (2001). Communication service quality is the key successful factor to broadband network, Retrieved September 20, 2011, from http://www.find.org.tw/find/home.aspx?page=news\&id=1363 
Huang, C. H. (2009). Cloud computing. Retrieved March 5, 2011 from NTU's Computer and Information Networking Center Web site: http://www.cc.ntu.edu.tw/chinese/epaper/0008/20090320_8008.htm

Huang, W., Schrank, H., \& Dubinsky, A. J. (2004). Effect of brand name on consumers' risk perceptions of online shopping. Journal of Consumer Behaviour, 4(1), 40-51.http://dx.doi.org/10.1002/cb.156

Igbaria, M., Parasuraman, S., \& Baroudi, J. J. (1996). A motivational model of microcomputer usage. Journal of Management Information Systems, 13(1), 127-143.

Kolter, P. (2003). Marketing management (11th ed.). Upper Saddle River, NJ: Prentice-Hall.

Lee, K. S., \& Tan, S. J. (2003). E-retailing versus physical retailing: A theoretical model and empirical test of consumer choice. Journal of Business Research, 56, 877-885.http://dx.doi.org/10.1016/S0148-2963(01)00274-0

Liebermann, Y., \& Stashevsky, S. (2002). Perceived risks as barriers to internet and e-commerce usage. Qualitative Market Research: An International Journal, 5(4), 291-300. http://dx.doi.org/10.1108/13522750210443245

Lin, C. H. (2006). A study on use intention of free/open source software. Unpublished master's thesis, Soochow University, Taiwan.

Lu, H. P., Hsu, C. L., \& Hsu, H. Y. (2005). An empirical study of the effect of perceived risk upon intention to use online applications. Information Management \& Computer Security, 13(2/3), 106-121.http://dx.doi.org/10.1108/09685220510589299

Mansour, S., \& Ali, Y. N. (2009). A survey of the effect of consumers'perceived risk on purchase intention in E-Shopping. Business Intelligence Journal, 2(2), 26-275.

Mathieson, K. (1991). Predicting user intention: comparing the technology acceptance model with theory of planned behavior. Information Systems Research, 2(3), 173-191. http://dx.doi.org/10.1287/isre.2.3.173

Meyer, J. P., \& Allen, N. J. (1997). Commitment in the workplace: Theory, research, and application. Thousand Oaks, CA: Sage Publications.

Mitchell, V. W. (1992). Understanding consumers' behavior: Can perceived risk theory help. Management Decision, 30, 26-31. http://dx.doi.org /10.1108/00251749210013050

Mitchell, V. W. (1999). Consumer perceived risk: Conceptualisations and models. European Journal of Marketing, 33(1/2), 163-195. http://dx.doi.org/10.1108/03090569910249229

Mohamed, A. (2009). A history of cloud computing. Retrieved March 09, 2011 from http://www.computerweekly.com/feature/A-history-of-cloud-computing

Mooney, S. F. (2000). Opportunities, traps abound in privacy risk. Property \& Casualty Risk \& Benefits Management, 104(26), 19.

Paul, P. (2001). Mixed signals. American Demographics, 23(7), 44-49.

Pires, G., Stanton, J., \& Eckford, A. (2004). Influences on the perceived risk of purchasing online. Journal of Consumer Behavior, 4(2), 118-131. http://dx.doi.org/10.1002/cb.163

Tan, S. J. (1999). Strategies for reducing consumer' risk aversion in internet shopping. Journal of Consumer Marketing, 16(2), 163-180. http://dx.doi.org/10.1108/07363769910260515

Taylor, S., \& Todd, P. (1995). Decomposition and crossover effects in the theory of planned behavior: A study of consumer adoption intentions. International Journal of Research in Marketing, 12(2), 137-155. http://dx.doi.org/10.1016/0167-8116(94)00019-K

Thompson, R. L., Higgins, C. A., \& Howell, J. M. (1991). Personal computing: Toward a conceptual model of utilization. MIS Quarterly, 15(1), 125-142. http://dx.doi.org/10.2307/249443

Ueltschy, L. C., Krampf, R. F., \& Yannopoulos, P. (2004). A cross-national study of perceived consumer risk towards online (internet) purchasing. Multinational Business Review, 12(2), 59-82. http://dx.doi.org/10.1108/1525383X200400010

Venkatesh, V. \& Morris, M. G. (2000). Why don't men ever stop to ask for directions? Gender, social influence, and their role in technology acceptance and usage behavior. MIS Quarterly, 24(1), 115-139. http://dx.doi.org/10.2307/3250981

Wang, C. K. (2009). A related study on the web usage intention and the affecting factors among smart phone 
users. Unpublished master's thesis, Shu-Te University, Taiwan.

Wikimedia. (2011). Cloud computing. Retrieved 21 $1^{\text {st }}$ March, 2011 from http://en.wikipedia.org/wiki/Cloud_computing

Xu, B., Lin, Z. G., \& Shao, B. J. (2010). Factors affecting consumer behaviors in online buy-it-now auctions. Internet Research, 20(5), 509-526.

Yu, K. P. (2009). A study on use intention of Thin Client in e-government environment. Unpublished master's thesis, National Kaohsiung First University of Science and Technology. 